\title{
Efektivitas Implementasi Model Pembelajaran Tematik Berbasis Teknohumanistik Dalam Pengembangan Nilai-Nilai Karakter Pada Siswa SD Dwijendra Denpasar
}

\author{
I Made Astra Winaya ${ }^{*}$ * \\ ${ }^{1}$ Program Studi Pendidikan Guru Sekolah Dasar (PGSD), FKIP, Universitas Dwijendra, Denpasar
}

\author{
A R T I C L E I N F O \\ Article history: \\ Received 31 Oktober 2018 \\ Accepted 30 November \\ 2018 \\ Available online 31 \\ Desember 2018 \\ Kata Kunci: \\ Pembelajaran Tematik; \\ Teknohumanistik; Nilai- \\ nilai Karakter; Siswa SD \\ Keywords: \\ Thematic Learning \\ Technohumanistik; \\ Character Values: \\ Elementary school students
}

\begin{abstract}
A B S T R A K
Tujuan dari penelitian ini adalah untuk (1) Mendeskripsikan profil SD Dwijendra. (2) Mengelaborasi nilai-nilai karakter pada siswa yang mengikuti pembelajaran tematik berbasis teknohumanistik. (3) Menganalisis efektifitas pengembangan nilai-nilai karakter pada siswa yang mengikuti pembelajaran tematik berbasis teknohumanistik. Jenis Penelitian ini merupakan penelitian deskriptif kualitatif. Lokasi penelitian dilaksanakan di SD Dwijendra Denpasar. Teknik pengumpulan data menggunakan instrumen kuisioner, wawancara, dan observasi. Hasil penelitian menunjukkan bahwa: Pertama, Berdasarkan rumusan visi tersebut, SD Dwijendra Denpasar berkomitmen untuk mewujudkan pendidikan yang seimbang antara penguasaan ilmu, prestasi dan juga sikap, dan tindakan yang mencerminkan nilai agama. Hal tersebut sejalan dengan konsep pendidikan tenohumanistik. Kedua, elaborasi nilai-nilai karakter yang dikembangkan dalam kegiatan pembelajaran dilaksanakan dengan menggunakan model tematik berbasis teknohumanistik menekankan pembelajaran yang mampu menghasilkan siswa yang memiliki aklah mulia. Ketiga, Berdasarkan hasil analisis penyebaran
\end{abstract} kuesioner, wawancara dan observasi terhadap siswa, guru dan kepala sekolah menunjukan pelaksanaan pembelajaran tematik berbasis teknohumanistik memiliki efektifitas yang sangat memuaskan terhadap pengembangan nilai-nilai karakter siswa.

\begin{abstract}
A B S T R A C T
The objectives of this study are to (1) Describe the profile of SD Dwijendra. (2) Elaborating character values on students who take technohumanistic based thematic learning. (3) Analyzing the effectiveness of the development of character values in students who take technocratic based thematic learning. This type of research is a qualitative descriptive study. The location of the study was conducted at SD Dwijendra Denpasar. Data collection techniques used questionnaire instruments, interviews, and observations. The results showed that: First, Based on the formulation of the vision, SD Dwijendra Denpasar is committed to creating a balanced education between mastering knowledge, achievements and attitudes, and actions that reflect religious values. This is in line with the concept of technohumanistic education. Second, the elaboration of character values developed in learning activities is carried out using technohumanistic thematic models that emphasize learning that is able to produce students who are noble. Third, Based on the results of the analysis of questionnaires, interviews, and observations of students, teachers and principals, the implementation of technohumanistic thematic learning has very satisfying effectiveness towards the development of student character values.
\end{abstract}




\section{Pendahuluan}

Pesatnya perkembangan dan pemanfataan teknologi digital di berbagai bidang kehidupan manusia yang menimbulkan terjadinya revolusi industry 4.0 yang tengah dihadapi oleh seluruh negara di dunia. Saat ini pemerintah Indonesia pun tengah fokus meningkatkan daya saing bangsa untuk dapat menghadapi revolusi industri 4.0 tersebut karena diprediksi memiliki potensi manfaat yang besar terhadap kemajuan negara. Sebagian besar pendapat mengenai potensi manfaat Industri 4.0 adalah mengenai perbaikan kecepatan fleksibilitas produksi, peningkatan layanan kepada pelanggan dan peningkatan pendapatan. Terwujudnya potensi manfaat tersebut akan memberi dampak positif terhadap perekonomian suatu negara. Industri 4.0 memang menawarkan banyak manfaat, namun juga memiliki tantangan yang harus dihadapi. Drath dan Horch (2014) berpendapat bahwa tantangan yang dihadapi oleh suatu negara ketika menerapkan Industri 4.0 adalah munculnya resistansi terhadap perubahan demografi dan aspek sosial, ketidakstabilan kondisi politik, keterbatasan sumber daya, risiko bencana alam dan tuntutan penerapan teknologi yang ramah lingkungan.

Dunia pendidikan sebagai pembentuk sumber daya manusia tentu perlu mendapat perhatian serius dari seluruh stakeholder sehingga nantinya dapat menghasilkan sumber daya manusia yang berkualitas dan kompetitif. Menurut Natajaya dan Dantes (2015) menjelaskan dunia pendidikan dewasa ini terlihat adanya kecenderungan pendidikan yang dilakukan semata-mata untuk penguasaan iptek merupakan suatu realitas yang harus disikapi, karena pendidikan tidak boleh hanya didasarkan pada penguasaan iptek saja, tetapi harus dikombinasi diorkestra secara terpadu dengan nilai-nilai kemanusiaan. Sejalan dengan itu, Winaya (2017) menyampaikan pendidikan dengan pola yang hanya menekankan knowlage, membawa dampak terhadap meningkatnya perilaku-perilaku menyimpang pada siswa. Perilakumenyimpang yang sering terjadi adalah seperti berbicara dan bersikap seenaknya (tidak sopan), pelanggaran tata tertib sekolah, menyontek, tawuran, cara berpakian yang kurang sopan, serta kurangnya pengamalan terhadap nilai-nilai keagamaan

Upaya pencegahan situasi tersebut salah satunya sudah tertuang dalam UU No 20 Tahun 2003 Tentang Sistem Pendidikan Nasional Bab II Pasal 3, disebutkan bahwa "Pendidikan nasional berfungsi mengembangkan kemampuan dan membentuk karakter serta peradaban bangsa yang bermartabat dalam rangka mencerdaskan kehidupan bangsa". Selain itu,

pada tanggal 6 September 2017 dikeluarkannya PP No.87/2017 tentang "Penguatan Pendidikan Karakter (PPK)” yang di sahkan oleh presiden Ir. Joko Widodo. Tentu hal tersebut perlu diimplementasikan dalam kehiduapan masyarakat. Untuk di sekolah-sekolah, dibutuhkan inovasi-inovasi pembelajaran yang mampu mengorkestra secara terpadu antar pengembangan pengetahuan, keterampilan dan sikap yang menunjukan nilai-nilai kemanusiaan. Di samping kesempatan yang seluas-luasnya disediakan, namun yang penting juga adalah memberikan pendidikan yang bermakna (meaningful learning). Bermakna artinya siswa akan memahami konsep-konsep yang mereka pelajari itu melalui pengalaman langsung dan menghubungkannya dengan konsep lain yang sudah mereka pahami.

Di era globalisasi dan reformasi pada saat ini telah terjadi pergeseran paradigma dalam pendidikan, yang menghendaki pendidikan yang menyelaraskan kemajuan Iptek dengan nilainilai kemanusiaan, dan menuntut suatu model pendidikan yang mampu mentransformasikan kemampuan itelektualitas dengan dasar keadaban yang kokoh, yang disebut dengan suatu model pendidikan teknohumanistik. Menurut Dantes (dalam Winaya, 2015) menjelaskan pendidikan teknohumanistik pada dasarnya merupakan suatu upaya dalam mentransformasikan iptek dan nilai-nilai keadaban yang didasarkan pada beberapa prinsip: (1) Pendidikan teknohumanistik agar mengembangkan "Core Ethical Values" sebagai basis dari inti karakter kemanusiaan yang baik, seperti: kepedulian, kejujuran, keterbukaan, tanggung jawab, dan rasa hormat pada diri sendiri dan orang lain, sebagai basis daripada karakter yang baik, yang mendasari penguasaan iptek, (2) Pendidikan teknohumanistik, seyogianya didefinisikan secara komprehensif, yang mencakup pikiran, perasaan, dan perilaku. (3) Dalam pendidikan formal, pendidikan teknohumanistik menuntut niat yang sungguh-sungguh, proaktif, komprehensif dan pendekatan yang dapat memacu nilai-nilai inti pada semua tahap kehidupan sekolah. Sekolah dalam melakukan pendidikan teknohumanistik, seyogyanya disorot melalui 
lensa moral dengan melihat segala sesuatu yang berpengaruh terhadap nilai-nilai karakter peserta didik, dan (4) Sekolah harus menjadi "a caring community". Sekolah harus menampakkan diri sebagai lembaga yang memiliki karakter yang baik.

Menurut sudrajat (dalam Winaya, 2017) menjelaskan pendidikan karakter selayaknya dikembangkan melalui tahap pengetahuan (knowing), pelaksanaan (acting), dan kebiasaan (habit). Dalam pembentukan karakter tidaklah cukup sebatas pada tingkat pengetahuan saja. Seseorang yang memiliki pengetahuan kebaikan belum tentu mampu bertindak sesuai dengan pengetahuannya, jika tidak terlatih (menjadi kebiasaan) untuk melakukan kebaikan tersebut. Karakter juga menjangkau wilayah emosi dan kebiasaan diri. Dengan demikian diperlukan tiga komponen karakter yang baik (components of good character) yaitu (1) pengetahuan tentang moral (moral knowing), (2) penguatan emosi tentang moral (moral feeling), dan (3) perbuatan bermoral (moral action). Sejalan dengan hal tersebut Zuchdi (2010) mengemukakan bahwa pengintegrasian nilai-nilai moral ke dalam kegiatan pembelajaran mesti disampaikan secara komprehensif, yaitu inkulkasi (penanaman) nilai moral, pemberian teladan, memfasilitasi pengembangan nilai moral dan pengembangan keterampilan hidup (soft skill).

Dalam rangka memperkuat pelaksanaan pendidikan karakter, menurut Saripudin D \& Komalasari K, (2017:7-9) mengidentifikasi adanya 18 nilai karaktarer yang bersumber dari agama, pancasila, budaya, dan tujuan pendidikan nasional, yaitu : (1) religius, (2) jujur,(3) toleransi,(4) disiplin,(5) kerja keras,(6) kreatif, (7) mandiri,(8) demokratis, (9) rasa ingin tahu,(10) semangat kebangsaan, (11) cinta tanah air,(12) menghargai prestasi,(13) bersahabat/komunikatif,(14) cinta damai, (15) gemar membaca, (16) peduli lingkungan, (17) peduli sosial, dan (18) tanggung jawab.

Menurut hasil penelitian yang dilakukan Winaya (2015) tetang analisis dimensi-dimensi pendidikan karakter yang perlu dimunculkan secara prioritas untuk pendidikan karakter berbasis teknohumanistik di SD se-kota Denpasar dan Kabupaten Badung yaitu persahabatan, loyalitas, suka menolong/rasa terharu, disiplin, tanggung jawab, pekerjaan, keberanian, ketekunan, kejujuran, dan keyakinan. Sejalan dengan itu, hasil penelitian Yuliasmini (2018) menyimpulkan pendidikan teknohumanistik berbasis pendidikan karakter sangat relevan diterapkan dalam dunia pendidikan khususnya bagi sekolah-sekolah guna meningkatkan dan menumbuhkembangkan watak dan moral yang baik bagi semua warga sekolah. Selain itu, Marvin Brekowitz (dalam Rohman. 2012) menyatakan pendidikan karakter memiliki peranan yang sangat penting dalam upaya peningkatan motivasi siswa dalam meraih prestasi akademik yang terbukti pada sekolah-sekolah di Amerika Serikat, Jepang, Cina dan Korea yang telah menerapkan pendidikan karakter sejak pendidikan dasar.

Pengaplikasian pendidikan teknohumanistik di sekolah merupakan usaha strategis untuk pencapaian tujuan pendidikan tentang penguasaan iptek, kebijakan dan kebaikan dalam rangka pembentukan karakter peserta didik. Di sekolah dasar transformasi pendidikan teknohumanistik diharapkan menggunakan pembelajaran tematik. Karena pembelajaran tematik adalah pembelajaran terpadu yang menggunakan tema sebagai pokok atau kajian yang memungkinkan dapat mengaitkan atau mengintegrasikan pencapaian tujuan-tujuan belajar beberapa mata pelajaran terkait sehingga memberikan pengalaman belajar secara langsung dan powerful kepada siswa. Demikian pula tema yang dimaksudkan disini adalah pokok pikiran atau gagasan pokok yang dijadikan pokok pembahasan dalam pembelajaran yang berkaitan dengan pengalaman anak didik.

Berdasarkan pemaparan tersebut, tujuan penelitian ini dapat diuraikan sebagai berikut. (1) Mengelaborasi nilai-nilai karakter yang dikembangakan dalam pembelajran tematik berbasis teknohumanistik pada siswa SD Dwijendra Denpasar. (2) Menganalisis efektifitas pengembangan nilai-nilai karakter pada pembelajaran tematik berbasis teknohumanistik yang diikuti oleh siswa SD Dwijendra Denpasar. Sehingga dapat bermanfaat dalam pengembangan sebuah model pembelajaran yang dinilai efektif dalam membentuk dan mengembangankan karakter siswa. Sejalan dengan hal tersebut Lickona (2001) mengatakan bahwa karakter mengalami pertumbuhan yang membuat suatu nilai menjadi budi pekerti, sebuah watak batin yang digunakan dalam merespon situasi melalui cara dengan penuh moral. 
Menurut Santrock (2011) mengungkapkan anak yang berada pada jenjang pendidikan sekolah dasar telah mengalami perkembangan keterampilan, bertintdak dan pengaruh sosial yang kompleks. Hal tersebut tentu akan berpengaruh terhadap anak dalam belajar bagaimana harus bersikap dalam situasi sosial atau interpersonal yang membentuk perilaku berdasarkan pada kebutuhan untuk dilihat dengan cara yang positif, seperti moral atau berbudi luhur, tetapi bagian lain berkaitan dengan bagaimana orang ingin melihat dan merasakan tentang mereka (Miller, Kraus, dan Veltkamp, 2005).

Pembelajaran tematik berbasis tenohumanistik memiliki arti yang sangat penting bagi pendidikan anak usia dini di sekolah dasar, diantaranya: (1) memberikan pengalaman belajar yang nyata dan langsung kepada anak dalam rangka membangun sistem pengetahuan yang bermakna, (2) memungkinkan anak dapat belajar sesuai dengan tingkat dan irama pertumbuhan dan perkembangan anak, (3) lebih sesuai dengan karakter anak belajar anak, antara lain: belajar secara utuh, belajar sambil bermain, belajar yang menyenangkan, belajar sambil melakukan dan bekerja sama.

\section{Metode}

Jenis penelitian ini merupakan penelitian deskriptif kulitatif. Menurut Nana Syaodih Sukmadinata (2011: 73), penelitian deskriptif kualitatif ditujukan untuk mendeskripsikan dan menggambarkan fenomena-fenomena yang ada, baik bersifat alamiah maupun rekayasa manusia, yang lebih memperhatikan mengenai karakteristik, kualitas keterkaitan antar kegiatan. Lokasi penelitian ini di SD Dwijendra Denpasar. Penelitian ini dilakukan terbatas pada tahap mengelaborasai dan menganalisis efektifitas pembelajaran tematik teknohumanistik terhadap pembentukan 18 karater bangsa pada siswa SD Dwijendra. Hal ini dikarenakan faktor waktu dan biaya yang tersedia. Populasi penelitian ini adalah siswa kelas V dan VI SD Dwijendra Denpasar. Penarikan sampel yang digunakan dalam penelitian ini adalah total sampling yaitu teknik pengambilan sampel dimana jumlah sampel sama dengan populasi (Sugiyono, 2007). Alasan mengambil total sampling karena jumlah populasi yang kurang dari 100 seluruh populasi yaitu 82 populasi yang terdiri dari siswa kelas V sebanyak 40 orang dan siswa kelas VI sebanyak 42 orang. Teknik pengumpulan data dalam penelitian ini adalah menggunakan wawancara, observasi dan penyebaran kuesioner.

Data penelitian ini berupa data kualitatif dan data kuantitatif. Oleh karena itu, pengolahan datanya menggunakan Mix Method yaitu campuran antara analisis kualitatif dan analisis kuantitatif. Analisis kualitatif digunakan pada data yang membutuhkan pemaknaan secara naratif baik pada content maupun proses. Sedangkan data hasil penyebaran kuesioner untuk mengukur efektifitas pengembangan nilai-nilai karakter pada siswa peserta pesrman kilat, analisis datanya menggunakan analisis deskiriptif kuantitatif.

\section{Hasil dan pembahasan}

\section{Profil SD Dwijendra Denpasar}

Sekolah SD Dwijendra Denpasar merupakan salah satu sekolah dasar swasta yang berada di daerah pusat pemerintahan Kota Denpasar. SD Dwijendra terletak di Jalan Kamboja No. 10 Kreneng Denpasar. Karena letaknya yang strategis dan terkenal dengan berbagai macam prestasi yang telah diraih sekolah ini, tidak heran bila sekolah ini menjadi salah satu sekolah favorit di Denpasar. Hal ini terlihat dari animo masyarakat yang ingin anaknya bersekolah di SD Dwijendra.

Adapun visi yang menjadi landasan utama bagi sekolah SD Dwijendra Denpasar, yaitu "Unggul dalam bidang akademik dan non akademik berwawasan budaya berdasarkan Srada dan bhakti". Berdasarkan rumusan visi tersebut, SD Dwijendra Denpasar berkomitmen untuk mewujudkan pendidikan yang seimbang antara penguasaan ilmu, prestasi dan juga sikap, dan tindakan yang mencerminkan nilai agama. Dalam pengimplementasian visi tersebut, SD Dwijendra sangat consent terhadap pengembangan nilai-nilai karakter di lingkungan sekolahnya.

Dalam pelaksanaan penanaman karakter di SD Dwijendra terdapat berbagai metode, program, dan cara yang diterapkan agar tercipta budaya sekolah yang kuat. Penanaman nilai- 
nilai 18 karakter bangsa melalui budaya sekolah mencakup semua kegiatan yang dilakukan kepala sekolah, guru, dan tenaga administrasi ketika berkomunikasi dan berinteraksi dengan para siswa baik di dalam kelas ataupun di luar kelas. Interaksi tersebut berkaitan dengan berbagai aturan, norma, moral serta etika bersama yang berlaku di sekolah tersebut.

2. Elaborasi nilai-nilai pendidikan karakter terhadap pelaksaan pembelajaran tematik berbasis teknohumanistik dalam pembelajaran di SD Dwijendra Denpasar

Dantes (dalam Yuliasmini, 2018) yang menyatakan pendidikan teknohumanistik hendaknya mengembangkan "Core Ethical Values" sebagai basis dari karakter kemanusiaan yang baik, seperti kepedulian, kejujuran, keterbukaan, tanggung jawab, dan rasa hormat pada diri sendiri dan orang lain adalah sebagai basis daripada karakter yang baik, yang mendasari penguasaan sain dan teknologi yang makin kompleks. Dalam penelitian ini, peneliti melakukan elaborasi terhadap 18 nilai karakter bangsa, yaitu : (1) religius, (2) jujur,(3) toleransi,(4) disiplin,(5) kerja keras,(6) kreatif, (7) mandiri,(8) demokratis, (9) rasa ingin tahu,(10) semangat kebangsaan, (11) cinta tanah air,(12) menghargai prestasi,(13) bersahabat/komunikatif,(14) cinta damai, (15) gemar membaca, (16) peduli lingkungan, (17) peduli sosial, dan (18) tanggung jawab dalam pemebalajaran tematik di kelas SD Dwijendra Denpasar Secara lengkap dapat dijabarkan sebagai berikut:

Pertama, religius. Penanaman nilai religius pada siswa terlihat dari berbagai kegiatan di sekolah yang bernuansakan ke agamaan. Bentuk pelaksanaan kegiatan religius adalah sebagai berikut. Siswa dipandu oleh guru mengucapkan matram Trisnadiya sebelum kegiatan pembelajaran dan pukul 12 siang. Setiap hari raya keagamaan dilaksanakan kegiatan persembahyangan bersama bagi seluruh siswa, guru, dan seluruh staf karyawan di SD Dwijendra. Kegiatan-kegiatan yang bernuansa religius selain menanamkan karakter religius secara langsung, juga menanamkan nilai-nilai karakter yang lain, seperti kedisiplinan, kepedulian, kebersamaan, saling menghormati.

Kedua, jujur. Karakter kejujuran dibangun di sekolah ini adalah dengan cara membiasakan siswa untuk berlaku jujur dalam kegiatan ujian atau ulangan, baik ujian harian, ujian tengah semester, ujian akhir semester, bahkan ujian akhir nasional. Tidak hanya dalam kegiatan ujian atau ulangan, dalam berbagai kegiatan sehari-hari siswa juga dibiasakan untuk selalu jujur dalam perbuatan maupun perkataan. Hasil pengamatan peneliti menemukan, siswa juga dilatih untuk bersikap jujur terhadap jam kedatangannya di sekolah dengan menyediakan papan yang berbentuk jam. Setiap hari siswa menyetel waktu jam pada papan tersebut sesuai dengan kedatanganya. Sehingga dengan kegiatan ini selain siswa mengembangkan sikap jujur tetapi juga kedisiplinan.

Ketiga, disiplin. Kegiatan-kegiatan yang menumbuhkan kedisiplinan dimulai dari membiasakan siswa, guru, kepala sekolah, beserta seluruh staf karyawan untuk tidak terlambat datang ke sekolah. Setiap siswa membuat semacam lembar perjanjian untuk selalu disiplin yang ditempel di depan kelas. Jika siswa melanggar kedisiplinan, guru akan mencatat pelanggaran tersebut dalam sebuah jurnal dan mendapat sanksi sesuai dengan janji yang mereka tulis di lembar perjanjian tersebut. Kedisiplinan ini tidak hanya yang berurusan dengan waktu, tetapi juga termasuk penggunaan seragam sekolah yang rapi, bersih, serta melengkapi dengan atributnya dan sesuai dengan ketentuan yang telah disepakati bersama. Setiap seminggu guru mengadakan pemeriksaan kerapian rambut untuk siswa laki-laki, ukuran panjang rambut tidak boleh melebihi telinga dan kerah baju.

Keempat, kerja keras. Untuk menanamkan sikap atau karakter kerja keras, sekolah memulainya dengan memasang atau memajang berbagai slogan dan moto mengenai kegiatan dalam bekerja dan belajar. Dengan adanya slogan-slogan dan moto yang terpasang di sudutsudut sekolah dan juga di dalam kelas, diharapkan menciptakan lingkungan belajar yang dapat memicu semangat siswa untuk selalu berusaha dan belajar guna mencapai cita-cita yang diinginkanya.

Kelima, kreatif. Penanaman karakter kreatif banyak dilakukan dalam kegiatan pembelajaran. Dalam hal ini, guru kelas memiliki peranan yang besar dalam menciptakan siswa yang kreatif. Berbagai kegiatan dilakukan untuk menumbuhkan sikap kreatif ini, antara lain 
dengan mengadakan pembelajaran yang menarik dan inovatif yang mendorong siswa untuk mengembangkan daya pikir dan bertindak kreatif. Kegiatan pembelajaran pun tidak hanya dilakukan di dalam kelas tetapi juga di halam sekolah. Hasil dari kreasi-kreasi yang telah dihasilkan oleh para siswa, baik di kelas maupun di sekolah diberikan tempat khusus untuk memajang. Hal tersebut adalah salah satu bentuk apresiasi terhadap berbagai bentuk hasil karya para siswanya sehingga hal ini dapat memicu siswa lain untuk turut bertindak kreatif. Sekolah juga mengapresiasi siswa-siswa yang berbakat dalam bidang seni dengan cara mengikutsertakan siswa yang berbakat seni dalam kegiatan perlombaan seperti perlombaan tari tradisional, tari modern, perlombaan seni lukis, perlombaan menyanyi, dengan diapresiasikan bakat-bakat seni siswa ini membuat siswa semakin terpacu untuk mengembangkan diri.

Keenam, demokrasi. Kegiatan yang mencerminkan karakter demokrasi telah banyak dilaksanakan, seperti kegiatan pemilihan ketua kelas dan pengurus kelas, pembagian regu-regu piket kelas. Dalam kegiatan pembelajaran juga banyak menanamkan budaya demokrasi seperti dalam pembentukkan kelompok belajar, dalam kegiatan diskusi kelas. Selain itu, dalam kegiatan pembelajaran tematik berbasis teknohumanistik di kelas, siswa diajak bermain peran untuk membentuk sikap demokratis.

Ketujuh, rasa ingin tahu. Sekolah membangun iklim yang membuat siswa memiliki rasa ingin tahu yang besar. Kegiatan pembelajaran yang mengeksplorasi lingkungan sekitar sekolah. Dalam kegiatan pembelajaran guru mengajak siswa untuk melakukan eksperimen dan pengamatan. Sekolah juga menyediakan perpustakaan sekolah dan wifi yang dapat diakses siswa, guru sebagai sarana untuk mempermudah mencari informasi.

Kedelapan, semangat kebangsaan dan cinta tanah air. Kegiatan yang mencerminkan sikap cinta tanah air melalui kegiatan upacara bendera hari Senin serta upacara peringatan hari-hari besar nasional, seperti upacara Hari Kemerdekaan dan Hari Pendidikan Nasional. Selain itu, juga memajang foto presiden dan wakil presiden serta lambang negara di setiap kelas dan tidak lupa memasang gambar pahlawan Indonesia. Siswa senantiasa dibiasakan menggunakan bahasa Indonesia yang baik dan benar untuk berkomunikasi dalam kegiatan pembelajaran. Serta setiap pagi sebelum masuk kelas siswa menyanyikan lagu kebangsaan Indonesia Raya di halam sekolah secara bersama-sama dengan sikap sempurna.

Kesembilan, bersahabat/komunikatif. SD Dwijendra meliliki kegiatan yang membangun persahabatan antar siswa, yaitu dengan cara menyediakan berbagai alat-alat permaian tradisional, seperti catur, congklak, hulahup, dan berbagai permaian tradisional yang lain. Dalam permaian ini, seluruh siswa dapat berinteraksi baik siswa dalam satu kelas, bahkan yang sudah terjadi di sekolah ini siswa dari kelas rendah (kelas1,2 dan 3) tidak merasa canggung atau takut bermain bersama dengan siswa kelas tinggi (kelas 4, 5, dan 6). Dari berbagai permainan inilah tercipta karakter persahabatan yang komunikatif. Kegiatan ini juga mencerminkan sikap toleransi.

Kesepuluh, peduli lingkungan. Kegiatan peduli lingkungan dimulai dari membiasakan siswa agar dapat bertanggung jawab pada dirinya sendiri. Kegiatan tersebut berupa membuang sampah pada tempatnya, cuci tangan sebelum dan sesudah makan, tidak mencorat-coret tembok maupun meja. Selanjutnya, siswa diberikan tanggung jawab untuk peduli pada lingkungan kelas masing-masing. Guru membagi kelas menjadi regu-regu piket untuk membersihkan lingkungan kelas setiap hari secara bergilir. Dalam kegiatan ini, siswa diberikan tanggung jawab atas kebersihan kelasnya. Untuk kegiatan kepedulian terhadap lingkungan sekolah dalam waktu sebulan sekali seluruh warga sekolah mengikuti kegiatan kerja bakti membersihkan lingkungan sekolah secara bersama-sama.

Kesebelas, peduli sosial. Kegiatan peduli sosial yang senantiasa dilakukan dan dibiaskan di sekolah ini antara lain menjenguk atau mengunjungi apabila ada teman yang sakit. Memberikan sumbangan baik berupa dana ataupun barang-barang, pakaian layak pakai pada saat momenmomen tertentu seperti terjadinya bencana alam, gunung meletus, banjir. Dengan membiasakan siswa untuk peduli dengan sesama maka diharapkan dapat menumbuhkan sikap empati dari setiap siswa.

Kedua belas, tanggung jawab. Berbagai kegiatan yang diadakan oleh SD Dwijendra untuk para siswa, memuntut peran aktif siswa dalam melaksanakannya dan tak lupa siswa diajarkan 
untuk bertanggung jawab atas semua kegiatan yang telah mereka kerjakan atau mereka perbuat. Untuk melatih rasa tanggung jawab kepada siswa, dimulai dari kegiatan di dalam kelas seperti siswa diberi tanggung jawab untuk mengerjakan pekerjaan rumah, melaksanakan tugas piket sesuai dengan jadwal yang telah disepakati bersama di kelas, dan juga membiasakan siswa untuk tidak curang dalam melaksanakan semua tugas-tugas yang diberikan kepada mereka. Untuk kegiatan dalam lingkup lingkungan sekolah, penanaman karakter bertanggung jawab dilakukan dengan cara melibatkan siswa dalam setiap kegiatan sekolah, seperti dalam kegiatan persiapan perayaan hari raya agama dan kegiatan HUT Yayasan sehingga siswa dapat memiliki rasa tanggung jawab atas kegiatan yang telah dipercayakan sekolah kepadanya dan mereka secara total berpartisipasi dalam seluruh kegiatan yang ada di sekolah.

Ketiga belas, gemar membaca. Dalam menumbuhkan keinginan siswa untuk membaca di SD Dwijendra dilakukan dengan melakukan kegiatan literasi sekolah 10 menit sebelum kegiatan pembelajaran dimulai. Siswa diberikan kebebasan untuk memilih bahan bacaan serta tempat yang meraka anggap nyaman untuk membaca. Sedangkan dalam kegiatan pembelajaran di kelas siswa di biasakan untuk membaca untuk mencari informasi tetang tema pembelajran yang akan dipelajari.

3. Efektivitas Pembelajaran Tematik Berbasis Teknohumanistik terhadap pengembangan Nilai-nilai Karakter Siswa SD Dwijendra Denpasar

Berdasarkan hasil pengisian kuesioner, obervasi, dan wawancara yang peneliti lakukan kepada siswa kelas V dan VI, guru serta Kepala Sekolah SD Dwijendra diperoleh data sebagai berikut:

1) Nilai Karakter Religius

Dari hasil kuesioner yang penulis sebarkan kepada responden, sebanyak 78 dari 82 reponden menyatakan bahwa dalam pikiran, perkataan dan tindakannya mengupayakan berdasarkan pada nilai-nilai ketuhanan atau agama. Menurut penuturan wali kelas V SD Dwijendra (hasil wawancara pada tanggal 27 Mei 2018) "Siswa wajib bertrisandya pada saat pagi sebelum masuk kelas dan tepat jam duabelas siang, selain itu, siswa juga diajak melaksanakan persembahyangan bersama dengan mengenakan pakaian adat setiap perayaan purnama, hari raya saraswati dan odalan di Pura Perahayangan Yayasan Dwijendra". Dalam kegiatan pembelajaran siswa sering diajak mendiskusikan tentang pentingnya toleransi antar umat beragama. Dengan cara ini siswa diharapkan mendalami nilai religius dari agama masing-masing, tetapi tidak mininggalkan toleransi antar umat beragama di Indonesia.

2) Nilai Karakter Kejujuran

Dari hasil kuesioner yang disebarkan kepada responden, sebanyak 76 siswa dari 82 responden menyatakan bahwa kejujuran harus dimiliki oleh setiap orang. Selama proses pembelajaran PPKn kejujuran dilatih melalui kegiatan-kegiatan sederhana di dalam kelas yang setiap harinya dilakukan sebagai suatu kebiasaan, yaitu prilaku membedakan milik pribadi atau milik orang lain.Hal-hal baik yang dilakukan oleh siswa sehingga mendapatkan apresiasi dari guru dan orang lain akan berpengaruh pada sikap dan prilakunya kelak dimasyarakat dan tentunya bergantung pada kondisi atau pengaruh lingkungan masyarakat disekelilingnya.

3) Nilai Karakter Disiplin

Hasil dari kuesioner yang penulis sebarkan kepada reponden, sebanyak 75 dari 82 siswa menyatakan bahwa disiplin memliki arti penting bagi mereka. Di SD Dwijendra hal tentang kedisplinan telah dicantumkan dalam ikrar pendidikan karakter dan tata tertib sekolah maupun visi \& misi sekolah agar terciptanya lingkungan sekolah yang berkarakter. Berdasarkan Penuturan kepala sekolah SD Dwijendra, ( wawancara, tanggal 27 mei 2018) mengatakan " pada sekarang ini, terlihat jelas betapa menurunnya tingkat kedisiplinan siswa, contohnya kebiasaan datang terlambat, kebiasaan melanggar, kebiasaan membuang sampah sembarangan dan sebagainya". Untuk itu perlu adanya penanaman kedsiplinan sejak dini. Kebiasaan datang terlambat kami siasati dengan memadukan kemajuan teknologi, yaitu menggunakan media face scan ( scan wajah).. Ketika siswa tidak scan wajah 
dan tidak berada di sekolah pada jam sekolah, guru piket yang bertugas pada saat itu akan langsung menghubungi keluarga atau orang tua siswa untuk mengkonfirmasi ketidakhadiran dari siswa tersebut.

4) Nilai Karakter TanggungJawab

Dari hasil kuesioner yang disebarkan kepada responden, sebanyak 75 siswa dari 82 responden menyatakan bahwa tanggungjawab memiliki arti penting bagi mereka. Tanggungjawab adalah perwujudan integritas. Di sekolah, penanaman tanggung jawab siswa adalah pembagian tugas piket secara bergiliran, baik di lingkungan piket kelas maupun piket area sekolah. Siswa diajarkan untuk memahami bahwa lingkungan kelas atau sekolah yang bersih akan membuat mereka nyaman dalam belajar. Siswa juga diajarkan bertanggungjawab akan kebersihan kelas bukan hanya pesuruh sekolah, tetapi seluruh warga terlibat di dalam sekolah. Agar piket berjalan dengan baik, guru juga bertanggung jawab dalam mendampingi dan mengawasi siswa piket. Sikap tanggungjawab juga diberikan guru pada saat kegiatan kerja kelompok. Anak diajarkan bersikap tekun mulai dari mempersiapkan keperluan kerja kelompok hingga selesai kegiatan evaluasi. Dengan memberikan kesempatan untuk menentukan target penyelesaian tugasnya. Hal ini sebagai bentuk pemberian kepercayaan baik perseorangan maupun kelompok untuk bertanggungjawab terhadap "janji" yang telah siswa ikrarkan.

Selain itu, ada aturan yang menarik di buat oleh guru kelas, yaitu melarang orang tua untuk membawakan barang-barang anakanya ke dalam sekolah dan membawakan barang atau tugas siswa yang ketinggalan di rumah ke sekolah. Menurut wali kelas V SD Dwijendra menuturkan awalnya aturan tersebut terasa berat bagi siswa dan tidak jarang membuat siswa menangis. Namun karena sosialisasi dan pemberian pemahaman yang berkelanjutan membuat pelaksanaan aturan ini berjalan efektif melatih tanggungjawab siswa untuk mempersiapkan lebih awal barang-barang yang akan dibawanya ke sekolah.

5) Nilai Karakter Toleransi

Dari wawancara yang penulis lakukan terhadap responden, sebanyak 73 siswa dari 82 responden menyatakan bahwa tolerasni memiliki arti penting. Melalui pembelajaran tematik berbasis Teknohumanistik di tanamkan toleransi melalui kegiatan diskusi masalahmasalah toleransi yang terjadi di Indonesia. Siswa dilatih peka dan berfikir kritis dalam menanggapi suatu permasalahan, wujud dari toleransi adalah suka menolong, peduli terhadap orang lain dan saling menghargai. Selain itu, nilai karakter toleransi ditanamkan juga melalui kegiatan sosial dalam mengumpulkan sumbangan sukarela untuk temannya yang sakit serta untuk korban bencana alam.

Intinya guru mengajarkan ketulusan hati, kegiatan seperti ini dapat membantu siswa mengembangkan empati, kepekaan, kepedulian, dan keiklasan untuk berbagi, serta mengembangkan rasa syukur terhadap hal-hal baik yang telah mereka dapatkan selama ini.

6) Nilai Karakter Kemandirian

Dari hasil observasi dan kuesioner yang peneliti lakukan terhadap responden, sebanyak 69 siswa dari 82 responden menyatakan bahwa karakter kemandirian memiliki arti penting dalam kehidupannya. Dalam pemebelajaran, sikap mandiri siswa dibiasakan dengan mengerjakan tugas secara mandiri dan memberikan kesempatan bertanya jika dirasa ada soal yang sulit untuk dijawab. Berdasarkan penyebaran hasil kuesioner sebanyak 69 siswa menjawab lebih merasa puas dengan hasil kerja yang telah dilakukan seara mandiri dari pada di bantu orang lain serta merasa malu mendapat pujian jika mengakui hasil kerja orang lain.

7) Nilai Karakter Bersahabat

Nilai karakter persahabatan di tanamkan di sekolah melalui kegiatan saling berkunjung dan bersilahturahmi. Ketika ada teman yang sedang sakit, guru mengajak siswa untuk berkunjung bersama melihat kondisi teman yang sedang sakit tersebut. Selain itu, guru membiasakan mengajarkan siswa untuk saling berbagi dalam suka maupun duka. Nilai karakter persahabatan juga ditanamkan pada siswa melalui kegiatan baris-berbaris untuk masuk ke dalam kelas. Jika barisan tidak lengkap siswa lain membantu untuk mencari temannya yang belum datang. Jika ada siswa yang tidak tertib, nyelonong begitu saja hal ini 
tentu saja akan membuat gaduh karena tman-temannya yang terlewati akan berteriak. Begitu juga dengan kehidupan bersama ada aturan, tatanan yang perlu untuk diperhatikan dan ditaati bersama agar semua dapat berjalan dengan tertib dan baik. Melalui pembelajaran ini setidaknya siswa sudah diajarkan dan dibiasakan untuk hidup bersama secara benar, baik dan tertib. Dari observasi dan kuesioner yang peneliti lakukan terhadap responden, sebanyak 69 siswa dari 82 responden menyatakan bahwa selalu menggunakan cara berpikir, berbuat dan bersikap yang menunjukan kesetiaan, kepedulian dan penghargaan yang tinggi terhadap persahabatan. Apalagi saat berada dalam kesulitan atau perlu bantuan. Responden menyatakan bahwa sahabatlah yang bisa diandalkan.

8) Nilai Karakter Kerja Keras

Dari hasil kuesioner yang peneliti sebarkan kepada responden, sebanyak 68 orang dari 82 responden menyatakan bahwa kerja keas memiliki arti penting bagi mereka dan mendapat hasil pekerjaan yang baik adalah harapan para responden. Di dalam pembelajaran guru sering memberikan gambaran tetang sejarah kemerdekaan dan berdirinya Negara Indonesia yang diperjuangkan oleh para leluhur pahlawan kita dengan semangat, kegigihan, kerja keras dan tekad sehingga teriptanya Negara Kesatuan Republik Indonesia sampai dengan saat ini. Dalam hal ini, siswa ditumbuhkan rasa semangat dan senantiasa bekerja keras khususnya dalam hal belajar dan kegiatan lainnya.

9) Nilai Karakter Peduli Lingkungan

Dari hasil kuesioner yang peneliti sebarkan kepada responden, sebanyak 68 siswa dari 82 responden menyatakan memiliki sikap peduli terhadap lingkungan. Menurut observasi dan wawancara yang peneliti lakukan kepada kepala sekolah, peneliti memperoleh konsep Tri Hita Karana (ajaran agama Hindu). Tri Hita Karana adalah hubungan manusia terhadap tiga unsur yang harmonis yaitu, hubungan manusia dengan Tuhan, hubungan manusia dengan sesama, hubunan manusia dengan lingkungan.

Hubungan Berdasarkan hasil observasi peneliti dalam percobaan sederhana dalam menanamkan sikap peduli lingkungan. Adapun percobaannya adalah menyuruh siswa menutup menutup hidung dan mulutnya beberapa saat dan melepaskannya jika udah merasa sesak. Kemudian dijelaskan setela membuka hidung kita dapat bernafas dengan lega karena ada oksigen. Oksigen di dapat dari tumbuh-tumbuhan yang ada di dilingkungannya. Nah dari penjelasan tersebut siswa diajak untuk peduli terhadap lingkungannya dengan memulai dari hal yang sederhana seperti, menanam pohon, membuang sampah pada tempatnya, menghemat penggunaan air dan lain sebagainya.

10) Nilai Karakter Kreatif

Dari hasil kuesioner yang peneliti sebarkan kepada responden, sebanyak 66 siswa dari 82 responden menyatakan bahwa sikap kreatif meliliki arti penting dalam kehidupanya. Dalam pembelajaran tematik, sikap kreatif siswa diasah melalui tugas yang diberikan untuk membuat kliping tentang kondisi pemerintahan Indonesia dengan semenarik mungkin, setelah itu siswa menceritakan dengan kata-kata sendiri tentang hasil kliping yang mereka buat. Daya imajinasi dan kreativitas siswa akan dilatih untuk mengolah kata-kata. Selain itu, setiap pembelajaran juga diupayakan mampu merangsang cara berpikir dan sikap kreatifitas siswa. Sikap kreatif siswa dalam bidang non akadamik juga di kembangkan dalam berbagai macam kegiatan ekstrakurikuler sesuai dengan minat dan bakatnya

11) Nilai Karakter Cinta Tanah Air

Dengan pembelajaran PPKn menunjukan siswa memiliki rasa cinta tanah air karena PPKn merupakan mata pelajaran yang mempelajari tentang Ideologi, politik, ekonomi, sosial, budaya, pertahanan dan keamanan dari pada bangsa Indonesia. Dari hasil kuesioner yang peneliti sebarkan kepada reponden, sebanyak 75 dari 82 responden menyatakan memiliki rasa cinta tanah air yang sangat tinggi. Karena bagi siswa, Indonesia adalah negara yang sangat unik yang sangat kaya akan sumber daya alam, budaya dan seni. Sikap kecitaanya terhadap tanah air di tunjukan oleh siswa dengan menggunakan bahasa Indonesia dalam berkomunikasi dan menyanyikan lagu Indonesia Raya dengan penuh semangat. Selain itu, siswa merasa banggga ikut berpartisipasi mementaskan tarian nusantara ketika HUT-RI ataupun HUT Yayasan Dwijendra. 
12) Nilai Karakter Rasa Ingin Tahu

Rasa ingin tahu merupakan sikap dan tindakan yang selalu berupaya untuk mengetahui lebih mendalam dan meluas dari sesuatu yang dipelajari, dilihat dan di dengar. Dalam pembelajaran tematik rasa ingin tahu dikembangkan melalui kegiatan presentasi, tanya jawab dan diskusi kelompok. Topik-topik yang dipilih sebagai bahan tanya jawab dan diskusi kelompok adalah berkaitan dengan tema pembelajaran. Dalam kegiatan tanya jawab dan diskusi, siswa sangat antusias dalam memberikan pertanyaan-pertanyaan dan tanggapan. Hal ini sejalan dengan hasil pengisian kuesioner yang dilakukan oleh siswa yang menunjukan 65 siswa dari 82 siswa memiliki rasa ingin tahu yang tinggi. Siswa selalu mencari informasi ter-update melalui internet dan antusias mendengar informasi baru dari orang lain. Hal tersebut dikarenakan mereka merasa tertantang terhadap hal baru dan selalu ingin mengetahui lebih banyak lagi.

13) Nilai Karakter Demokratis

Pembentukan sikap demokratis pada pembelajaran tematik di kelas V dan VI di awali dengan pemilihan pengurus perangkat kelas dan pembagian piket kelas yang dilakukan demokratis dengan mengedepankan musyawarah mufakat. Selain itu siswa dibiaskan untuk menghargai pilihan orang lain dan tidak memaksakan kehendak. Berdasarkan hasil pengisian kuesioner yang dilakukan oleh siswa menunjukan 65 dari 82 orang siswa menyatakan mereka selalu meminta pendapat orang lain untuk memecahkan suatu masalah bersama atau mengambil keputusan untuk kepentingan bersama dan mereka selalu menghargai pendapat temannya.

14) Nilai Karakter Menghargai Prestasi

Sikap menghargai prestasi merupakan sikap dan tindakan yang mendorong dirinya untuk menghasilkan sesuatu yang berguna bagi masyarakat, mengakui, dan menghormati keberhasilan orang lain. Hal ini ditunjukan siswa selama mengikuti proses pembelajaran dengan memberi tepuk tangan kepada temannya yang berani berpendapat, bertanya ataupun tampil. Selain itu, berdasarkan pengisian jawaban kuesioner oleh siswa, sebanyak 72 orang dari 82 siswa menyatakan siap untuk mengucapkan selamat kepada temannya yang berprestasi dan sangat bangga dengan prestasi yang ia raih, ditunjukan dengan tandatanda penghargaan yang diperlolehnya dengan baik. Selain itu, setiap siswa yang berprestasi baik di kegiatan akademik ataupun non-akademik biasanya akan diumukan dalam kegiatan upacara bendera hari senin dan profilnya akan dimuat dalam majalah dinding sekolah.

15) Nilai Semangat Kebangsaan

Semangat kebangsaan merupakan cara berfikir, bertindak, dan berwawasan yang menempatkan kepentingan bangsa dan negara di atas kepentingan diri dan kelompok. Dalam pembelajaran PPKn tentunya banyak nilai semangat kebangsaan yang diperoleh karena PPKn mempelajari tentang Ideologi, Politik, Ekonomi, Sosial, Budaya, Pertahanan dan Keamanan Bangsa dan Negara Indonesia. Dan juga guru memberikan sejarah perjuangan Bangsa Indonesia untuk mengingat sejarah perjuangan bangsa Indonesia.

16) Nilai Karakter Cinta Damai

Cinta damai adalah sikap perkataan dan tindakan yang menyebabkan orang lain merasa senang dan aman atas kehadiran dirinya. Selama observasi peneliti tidak menemukan kasus pertengkaran atau bulliying di kalangan siswa di SD Dwijendra. Melainkan mereka begitu akrab layaknya saudara. Selain itu, berdasarkan hasil pengisian kuesioner menunjukan 65 orang dari 82 siswa menyatakan selalu berbicara sopan dan berusaha bersikap yang membuat orang lain nyaman.

17) Nilai Karakter Peduli Sosial

Sikap peduli sosial merupakan sikap dan tindakan yang selalu ingin memberi bantuan pada orang lain dan masyarakat yang membutuhkan. Sikap ini dikembangakan dalam pembelajaran dengan mengajak siswa untuk berempati terhadap tragedi kemanusian yang terjadi di beberapa daerah di Indonesia dan Dunia. Dengan pemahaman yang di dapat tersebut, di sekolah siswa menunjukan sikap kepedulian sosialnya dengan berempati melihat ada temannya sakit. Dan membuat kotak donasi untuk membantu temannya yang 
rawat inap di ruamh sakit. Hal ini juga diperkuat dengan hasil kuesioner yang diisi oleh 82 orang, 73 orang siswa yang menyatakan akan menjenguk teman yang sakit dan mendoakannya agar cepat sembuh.

18) Nilai Karakter Gemar Membaca

Gemar membaca merupakan kebiasaan menyediakan waktu untuk membaca berbagai bacaan yang memberikan kebajikan bagi dirinya. Dari hasil kuesioner yang penulis sebarkan kepada responden, sebanyak 61 orang dari 82 responden menyatakan gemar membaca. Kegiatan literasi sekolah selama 10 menit sebelum kegiatan pembelajaran dimulai sangat efektif meningkatkan minat baca siswa. Siswa menjadi terbiasa membaca setiap menemukan bahan bacaan. Siswa juga sering ditugaskan untuk mencari dan membaca artikel di internet sesuai dengan tema pembelajaran yang sedang dibahas. Hal ini karena sebagain besar siswa sudah terbiasa menggunakan internet dan menjadikan kegiatan pembelajaran menjadi lebih bermakna.

\section{Simpulan dan saran}

Berdasarkan dari hasil pelaksanaan penelitian yang telah dilakukan dapat disimpulkan beberapa hal berikut ini. Pertama, Berdasarkan rumusan visi tersebut, SD Dwijendra Denpasar berkomitmen untuk mewujudkan pendidikan yang seimbang antara penguasaan ilmu, prestasi dan juga sikap, dan tindakan yang mencerminkan nilai agama. Hal tersebut sejalan dengan konsep pendidikan tenohumanistik. Kedua, elaborasi nilai-nilai karakter yang dikembangkan dalam kegiatan pembelajaran dilaksanakan dengan menggunakan model tematik berbasis teknohumanistik menekankan pembelajaran yang mampu menghasilkan siswa yang memiliki aklah mulia. Ketiga, Berdasarkan hasil analisis penyebaran kuesioner, wawancara dan observasi terhadap siswa, guru dan kepala sekolah menunjukan pelaksanaan pembelajaran tematik berbasis teknohumanistik memiliki efektifitas yang sangat memuaskan terhadap pengembangan nilai-nilai karakter siswa. Hal tersebut terjadi karena pengembangan nilai-nilai karakter dalam kegiatan pasraman kilat tidak hanya terbatas pada aspek pengetahuan saja, melainkan sikap dan pengulangan untuk membentuk sebuah kebiasaan yang baik.

Berdasarkan temuan penelitian, pembahasan dan reflesi akademik terkait dengan teori sejenis serta keunggalan yang dimiliki oleh pembelajran tematik berbasis teknohumanistik maka dapat diformulasikan saran sebagai berikut: bahwa hasil penelitian menunjukan pembelajran efektif dalam mengembangkan pendidikan karakter. Untuk itu, perlu diperkenalakan dan dikembangkan lebih lanjut kepada guru, siswa dan praktisi pendidik lainnya sebagai inovasi dalam pembelajaran. Serta perlu melakuan penelitian lebih lanjut untuk mengatasi rendahnya minat baca siswa.

\section{Daftar Rujukan}

Arnyana, I. B. P. 2004. Pengembangan Perangkat Model Belajar Berdasarkan Masalah dipandu Strategi Kooperatif serta Pengaruh Implementasinya terhadap Kemampuan Berpikir Kritis dan Hasil Belajar Siswa Sekolah Menengah Atas pada Pelajaran Ekosistem. Disertasi (tidak diterbitkan) PSSJ Biologi: PPS Universitas Negeri Malang.

Depdiknas. 2008. Rancangan Penilaian Hasil Belajar. Jakarta: Depdiknas.

Dick, W. and Carey L. 1990. Systematic Design of Instruction. (3rd Ed). New York: Harper Collins Publisher.

Hamdu, Ghullam dan Lisa Agustina. 2015. Pengaruh Motivasi Belajar Siswa terhadap Pestasi Belajar IPA di Sekolah Dasar (Studi Kasus terhadap Siswa Kelas IV SDN Tarumanagara Kecamatan Tawang Kota Tasikmalaya). Jurnal Universitas Pendidikan Indonesia, 11(1).

Karli, Hilda. 2015. Penerapan Pembelajaran Tematik SD di Indonesia. EduHumaniora, 2(1).

Lasmawan.2010. Menelisik Pendidikan IPS dalam Persepektif Kontekstual Empirik. Singaraja: Mediakom Indonesia Press Bali.

Mungin, E.W. 2012. Mengurai Realita dan Problematika Pendidikan Dasar Serta Antisipasi Menghadapi Globalisasi. Makalah disajikan dalam Seminar Nasional Kajian Pendidikan Dasar Uneversitas Pendidikan Ganesha pada tanggal 11 April 2012. 
Natajaya, I Nyoman dan Nyoman Dantes.2015. Perancangan Model Transpormasi Pendidikan Teknohumanistik yang Terintegrasi dengan Pembelajaran Tematik Di Sekolah Dasar. Jurnal Pendidikan Ganesha. 4(1).

Setyosari, P. 2010. Metode Penelitian Pendidikan dan Pengembangan. Jakarta: Kencana Prenada Media Group.

Suartama, I K dan I K Sudarma. 2007. Pengembangan Compac Disc Multimedia Interaktif pada Mata Kuliah Media Pembelajaran. Laporan Penelitian. Undiksha Singaraja.

Sugiyono. 2010. Metode Penelitian Pendidikan pendekatan kuantitatif, kualitatif dan $R \& D$. Bandung: Alfabeta

Sutjiono, T. A. S. 2005. Pendayagunaan media pembelajaran. Jurnal Pendidikan Penabur. 4(4).

Trianto. 2010. Model Pembelajaran Terpadu-Konsep, Strategi, dan Implementasinya dalam Kurikulum Tingkat Satuan Pendidikan (KTSP). Surabaya: Bumi Aksara.

Yuliani. 2011. Pengembangan Multimedia Pembelajaran IPS untuk Siswa SMP Kelas VII. Tesis (tidak dipublikasikan). Surakarta: FTP UNS.

Wena, Made (2010). Strategi Pembelajaran Inovatif Kontemporer . Jakarta: Bumi aksara.

Winaya, I Made Astra. 2013. Pengaruh Model ARCS Terhadap Hasil Belajar Ditinjau dari Motivasi Belajar Siswa pada Pembelajaran IPS di Kelas IV SD CHIS Denpasar. Jurnal Pascasarjana Undiksha. 3(1).

Winaya, I Made Astra. 2016. Pengaruh Model Quantum Teaching terhadap Hasil Belajar ditinjau dari Keterampilan Berpikir Kritis Siswa pada Pembelajaran IPA di Kelas V SD N. 1 Selanbawak. Jurnal Kajian Pendidikan Widya Accarya.

Komalasari K,Saripudin D.2017. Pendidikan Karakter: Konsep dan Evaluasi Living Values Education. Bandung: Refika Aditama

Santrock, J.W. 2011. Masa Perkembangan Anak. Buku 2 Edisi 11. Terjemahan Verawati Pakpahan \& Wahyu Anugraheni. Jakarta: Salemba Humanika. 